\title{
Penerapan Metode Fuzzy Multi Attribut Decision Making (FMADM) dan Simple Additive Weighting (SAW) untuk Penentuan Bujang Dayang Kota Pangkalpinang
}

\author{
Parlia Romadiana \\ ISB Atma Luhur \\ Pangkalpinang, Indonesia \\ parliaromadiana@atmaluhur.ac.id
}

\author{
Fitriyanti \\ ISB Atma Luhur \\ Pangkalpinang, Indonesia \\ fitriyanti@atmaluhur.ac.id
}

\author{
Delpiah Wahyuningsih \\ ISB Atma Luhur \\ Pangkalpinang, Indonesia \\ delphibabel@atmaluhur.ac.id
}

\begin{abstract}
Kegiatan pemilihan bujang dayang merupakan kegiatan yang rutin dilaksanakan setiap tahun di Kota Pangkalpinang. Pemilihan bujang dan dayang ini merupakan salah satu bentuk pelestarian dan aktualisasi adat budaya daerah Kota Pangkalpinang serta berusaha menampilkan nilai budaya masyarakat yaitu busana tradisional dan tari tradisional sebagai bagian dari nilai budaya yang harus dipertahankan kelestariannya. Dalam penentuan pemenang bujang dayang kota Pangkalpinang, dilakukan beberapa tahapan dalam proses penilaian dimana membutuhkan perhitungan yang akurat agar menghasilkan keputusan pemenang yang sesuai dengan nilai yang sudah dimiliki oleh masing-masing finalis. Dalam proses penentuan pemenang terdapat kendala yaitu lamanya proses perhitungan dalam perangkingan dalam menentukan pemenang bujang dayang kota pangkalpinang karena masih dilakukan secara manual. Dari kendala tersebut, maka peneliti ingin membuat sistem untuk menunjang pengambilan keputusan dalam pemilihan bujang dayang dengan menggunakan metode Fuzzy Multiple Attribute Decision Making (FMADM) dan Simple Additive Weighting (SAW) dimana akan ditentukan kriteria dan bobot sebagai dasar untuk mengembangkan sistem, kemudian membuat variabel dan mengkonversikan ke FMADM lalu dilakukan penyeleksian menggunakan SAW sehingga nantinya akan didapatkan hasil dari pemenang bujang dayang kota Pangkalpinang.
\end{abstract}

Kata kunci - Bujang Dayang, Fuzzy Multiple Attribute Decision Making, Simple Additive Weighting, sistem pengambilan keputusan.

\section{Pendahuluan (Heading 1)}

Pemanfaatan teknologi yang berkembang dapat membuat proses penginputan dan pengolahan data menjadi lebih efektif dan efisien dilihat dari berbagai macam perkembanga sistem informasi yang ada. Saat ini Sistem Pengambilan Keputusan (SPK) Sudah banyak diteliti untuk kepentingan pengambilan keputusan diantaranya untuk kasus kasus pemilihan personalia untuk perusahaan[1], pemilihan makanan terbaik[2], prioritas pembangunan jalan[3], kenaikan gaji karyawan[4], penjurusan sekolah[5], Pengembangan Industri Kecil Dan Menengah[6], dan masih banyak yang lainnya.

Dari penelitian tersebut, peneliti melihat belum banyak yang meneliti tentang prioritas dalam memilih putra putri terbaik di setiap wilayah. Di Indonesia, setiap kota/kabupaten melaksanakan ajang pemilihan putra putri terbiak untuk nantinya menjadi perwakilan dalam pemilihan diajang tingkat nasional. Salah satu kota yang melaksanakan kegiatan pemilihan putra putri terbaik yaitu Pemerintah Kota Pangkalpinang melalui Dinas Pendidikan dan Kebudayaan Kota Pangkalpinang menyelenggarakan kegiatan pemilihan Bujang Dayang Kota Pangkalpinang. Kegiatan ini merupakan kegiatan yang rutin dilaksanakan setiap tahunnya. Pemilihan bujang dan dayang ini merupakan salah satu bentuk pelestarian dan aktualisasi adat budaya daerah Kota Pangkalpinang serta berusaha menampilkan nilai budaya masyarakat yaitu busana tradisional dan tari tradisional sebagai bagian dari nilai budaya yang harus dipertahankan kelestariannya.

Dalam penentuan pemenang bujang dayang kota Pangkalpinang, dilakukan beberapa tahapan dalam proses penilaian yang melibatkan banyak peserta dan banyak juri. Peserta mempunyai kemampuan yang hampir sama dalam setiap kriteria penilaian sehingga menyulitkan para juri. Proses penilaian membutuhkan perhitungan yang akurat agar menghasilkan keputusan pemenang yang sesuai dengan nilai yang sudah dimiliki oleh masing-masing peserta. Proses penilaian dimulai dengan tahapan seleksi dimana semua peserta yang mendaftarkan diri dilakukan penilaian dan dari peserta seleksi tersebut yang lolos penilaian akan masuk ke tahapan terakhir yaitu grandfinal. Dalam proses penilaian terebut, masih dilakukan secara manual sehingga menyulitkan pihak juri dalam menentukan pemenang bujang dayang secara akurat dan cepat.

Penggunaan metode FMADM dan SAW untuk pengambilan keputusan di Kota Pangkalpinang sudah pernah digunakan dalam berbagai pengambilan keputusan diantaranya sistem pengambilan keputusan peserta didik baru[7], sistem pengambilan keputusan pemilihan sekolah dasar[8], dan sistem pengambilan keputusan rekomendasi kelayakan peserta rumah sehat baznas[9]. Dari berbagai sistem pengambilan keputusan menggunakan metode FMADM dan SAW yang sudah dilakukan di kota 
Pangkalpinang, belum ada yang menggunakan metode tersebut dalam pengambilam keputusan pemilihan bujang dayang kota Pangkalpinang.

Berdasarkan latar belakang diatas, maka peneliti ingin meneliti apa saja saja kriteria yang tepat yang menjadi parameter penentuan bujang dayang kota pangkalpinang, melakukan pemeringkatan terhadap pemilihan bujang dayang kota pangkalpinang menggunakan metode FMADM dan SAW.

Penelitian ini memiliki tujuan untuk mengetahui kriteria yang tepat dalam pengambilan keputusan bujang dayang kota Pangkalpinag, Menghitung bobot dari setiap kriteria yang menjadi parameter penentuan bujang dayang kota pangkalpinang, menerapkan metode FMADM dan SAW untuk penentuan bujang dayang kota pangkalpinang.

\section{METODOLOGI PENELITIAN}

\section{A. Memilih Model (Heading 2)}

FMADM atau kepanjangan dari Fuzzy Multiple Attribute Decision Making, adalah suatu metode yang digunakan untuk mencari alternatif optimal dari sejumlah alternatif dengan kriteria tertentu [10]. Inti dari FMADM adalah menentukan nilai bobot untuk setiap atribut, kemudian dilanjutkan dengan proses perankingan yang akan menyeleksi alternatif yang sudah diberikan. Pada dasarnya, ada 3 pendekatan untuk mencari nilai bobot atribut yaitu pendekatan subyektif, pendekatan obyektif dan pendekatan integrasi antara subyektif \& obyektif[11]. Masing- masing pendekatan memiliki kelebihan dan kelemahan. Pada pendekatan subyektif, nilai bobot ditentukan berdasarkan subyektifitas dari para pengambil keputusan sehingga beberapa faktor dalam proses perankingan alternatif bisa ditentukan secara bebas[12]. Sedangkan pada pendekatan obyektif, nilai bobot dihitung secara matematis sehingga mengabaikan subyektifitas dari pengambil keputusan.

Dari FMADM akan dilakukan penyeleksian dengan menggunakan Simple Additive Weighting (SAW) yaitu mencari penjumlahan terbobot dan rating kinerja pada setiap alternatif pada semua atribut yang ada[13]. Berikut tahapan metode Simple Additive Weighting (SAW) :

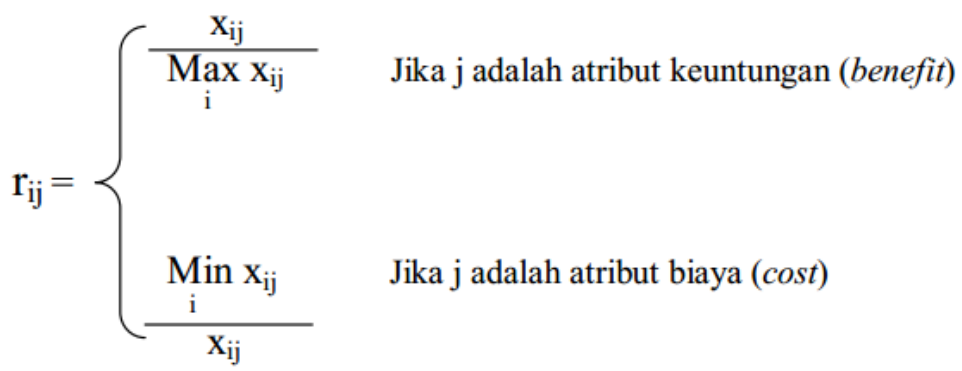

Rumus Normalisasi

Keterangan :

rij $\quad=$ nilai rating kinerja ternormalisasi

xij = nilai atribut yang dimiliki dari setiap kriteria

Max xij = nilai terbesar dari setiap kriteria

i

Min xij = nilai terkecil dari setiap kriteria

i

benefit $=$ jika nilai terbesar adalah terbaik

cost $\quad=$ jika nilai terkecil adalah terbaik

Dimana rij adalah rating kinerja ternormalisasi dari alternatif $\mathrm{Ai}$ pada atribut $\mathrm{Cj} ; \mathrm{i}=1,2, \ldots, \mathrm{m}$ dan $\mathrm{j}=1,2, \ldots, \mathrm{n}$. Nilai preferensi untuk setiap alternatif (Vi) diberikan sebagai:

$$
\mathrm{V}_{\mathrm{i}}=\sum_{\mathrm{j}=1}^{\mathrm{n}} \mathrm{W}_{\mathrm{j}} \mathbf{r}_{\mathrm{ij}}
$$

\section{Rumus Preferensi}


Keterangan :

$\mathrm{Vi} \quad=$ rangking untuk setiap alternatif

wj $\quad=$ nilai bobot dari setiap kriteria

rij $\quad=$ nilai rating kinerja ternormalisasi

Nilai Vi yang lebih besar mengindikasikan bahwa alternatif Ai lebih terpilih.

B. Alur Penelitian

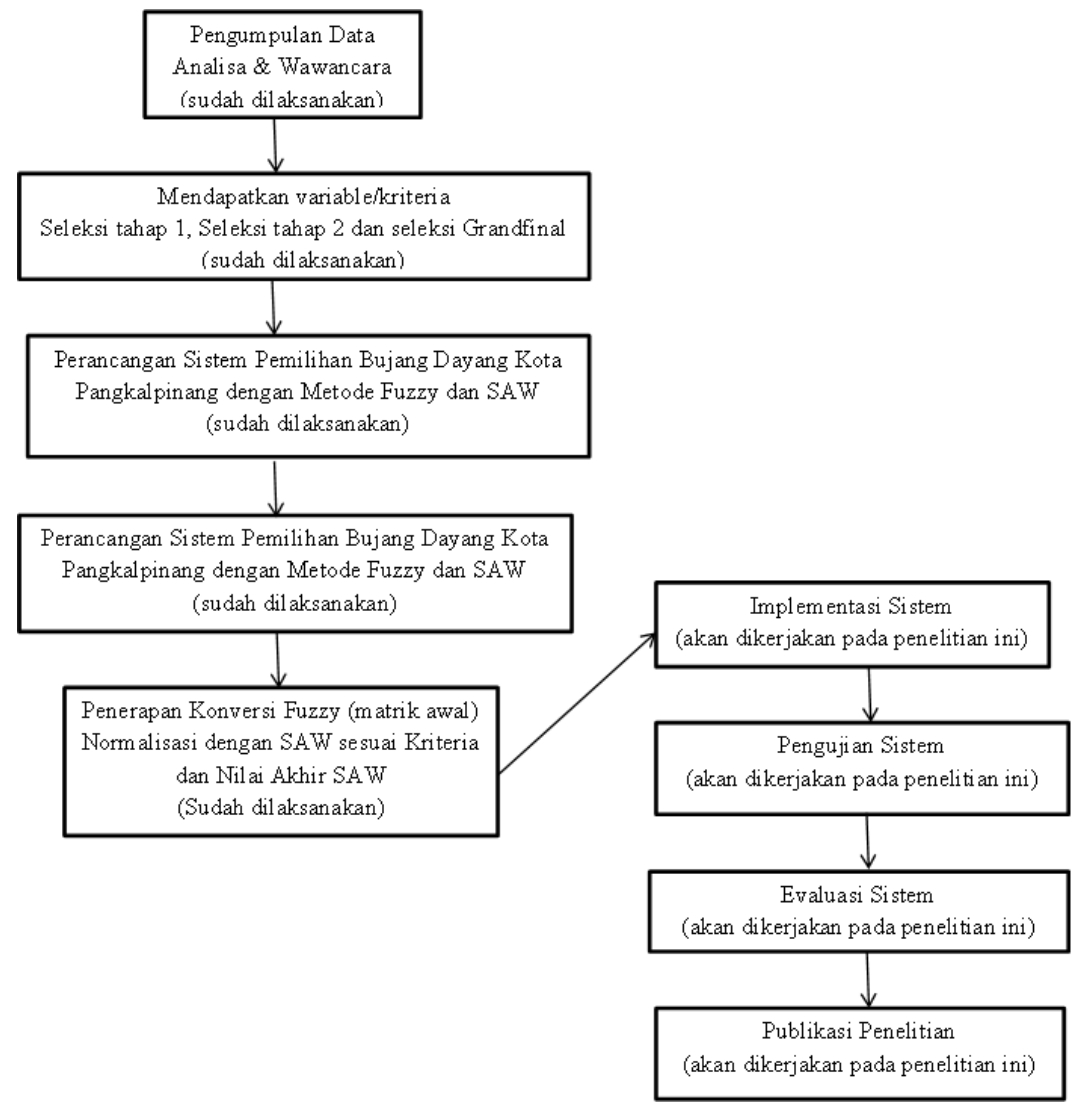

Gambar 1. Alur Penelitian

Dalam tahapan perencanaan sistem, penulis melakukan pengumpulan data dengan melakukan metode observasi langsung ke Dinas Pendidikan dan Kebudayaan Kota Pangkalpinang dan melakukan wawancara kepada Kepala Bidang Kebudayaan yang bertugas mengendalikan kegiatan bujang dayang kota Pangkalpinang setiap tahunnya. Penulis juga melakukan studi literature untuk menambah pengetahuan dan keterkaitan penelitian dengan penelitian yang sudah dilakukan sebelumnya. Setelah dilakukan tahapan perencanaan sistem, penulis menganalisis kegiatan berjalan dan menganalisa kebutuhan-kebutuhan yang diperlukan berdasarkan data yang sudah diperoleh dari tahapan perencanaan sistem. Selanjutnya penulis melakukan analisis kriteria-kriteria yang dibutuhkan dalam membuat sistem pengambilan keputusan penentuan bujang dayang kota Pangkalpinang. Metode yang digunakan dalam penelitian ini yaitu menggunakan metode FMADM dan SAW untuk menentukan pemenang bujang dayang kota Pangkalpinang. Penerapan metode FMADM digunakan dalam tahapan awal yaitu kriteria yang sudah ditentukan kemudian diberikan bobot. Dari masing-masing bobot tersebut, maka dibuat suatu variabel-variabelnya. Dimana dari suatu variabel tersebut akan dirubah kedalam bilangan fuzzy. Setelah dilakukan konversi ke FMADM, maka tahap selanjutnya melakukan penyeleksian menggunakan Simple Additive Weighting (SAW).

\section{HASIL DAN PEMBAHASAN}

\section{A. Analisa Bobot}

Adapun bobot yang dimiliki masing-masing kriteria yaitu:

TABEL 1. Nilai Bobot dari Kriteria

\begin{tabular}{|c|c|c|}
\hline No & Kriteria & Bobot \\
\hline \multicolumn{3}{|c|}{ Seleksi Tahap 1 } \\
\hline 1 & Brain & 0,30 \\
\hline
\end{tabular}




\begin{tabular}{|c|c|c|}
\hline 2 & Behaviour & 0,25 \\
\hline 3 & Brave & 0,25 \\
\hline 4 & Beauty & 0,20 \\
\hline \multicolumn{3}{|c|}{ Seleksi Tahap 2 } \\
\hline 5 & Public Speacking & 0,40 \\
\hline 6 & Unjuk bakat & 0,30 \\
\hline 7 & Anjangsana & 0,20 \\
\hline 8 & Table Manner & 0,10 \\
\hline \multicolumn{3}{|c|}{ Seleksi Grand Final } \\
\hline 9 & Tanya Jawab & 0,50 \\
\hline 10 & Penampilan & 0,30 \\
\hline 11 & Gesture Tubuh \\
\hline
\end{tabular}

\section{B. Konversi FMADM}

Dari hasil analisa kriteria didapatkan variabel dari setiap kriteria yang akan dikonversikan kedalam bilangan fuzzy sebagai berikut:

Tahapan pertama dilakukan seleksi awal dengan variabel dari setiap ktiteria sebagai berikut:

1) Kriteria Seleksi Tahap 1

Variabel dari kriteria seleksi tahap 1 dikonversikan kedalam bilangan fuzzy seperti terlihat pada tabel 2.

TABEL 2. Konversi FMADM dari kriteria Seleksi Tahap 1

\begin{tabular}{|c|c|c|c|c|c|}
\hline No. & Nilai & Brain & Behaviour & Brave & Beauty \\
\hline 1 & 0 & Tidak Menguasai & Tidak Baik & Tidak Baik & Tidak indah \\
\hline 2 & 0,5 & Kurang Menguasai & Kurang Baik & Kurang Baik & Kurang Indah \\
\hline 3 & 0,75 & Menguasai & Baik & Baik & Indah \\
\hline 4 & 1 & Sangat Menguasai & Sangat Baik & Sangat Baik & Sangat Indah \\
\hline
\end{tabular}

2) Kriteria Seleksi Tahap 2

Variabel dari kriteria seleksi tahap 2 dikonversikan kedalam bilangan fuzzy seperti terlihat pada tabel 3.

TABEL 3. Konversi FMADM dari kriteria Seleksi Tahap 2

\begin{tabular}{|c|c|c|c|c|c|}
\hline No. & Nilai & Public Speaking & Unjuk Bakat & Table Manner & Angjangsana \\
\hline 1 & 0 & Tidak Menguasai & Tidak Baik & Tidak Baik & Tidak indah \\
\hline 2 & 0,5 & Kurang Menguasai & Kurang Baik & Kurang Baik & Kurang Indah \\
\hline 3 & 0,75 & Menguasai & Baik & Baik & Indah \\
\hline 4 & 1 & Sangat Menguasai & Sangat Baik & Sangat Baik & Sangat Indah \\
\hline
\end{tabular}

3) Kriteria Seleksi Grand Final

Variabel dari kriteria seleksi granfinal dikonversikan kedalam bilangan fuzzy seperti terlihat pada tabel 4.

TABEL 4. Konversi FMADM dari kriteria Seleksi Grand Final

\begin{tabular}{|c|c|c|c|c|}
\hline No. & Nilai & Tanya Jawab & Penampilan & Gesture Tubuh \\
\hline 1 & 0 & Tidak Menguasai & Tidak Baik & Tidak Baik \\
\hline 2 & 0,5 & Kurang Menguasai & Kurang Baik & Kurang Baik \\
\hline 3 & 0,75 & Menguasai & Baik & Baik \\
\hline 4 & 1 & Sangat Menguasai & Sangat Baik & Sangat Baik \\
\hline
\end{tabular}

C. Rancangan Usulan

Usulan dari sistem yang akan dikembangkan digambarkan dalam use case diagram sebagai berikut: 


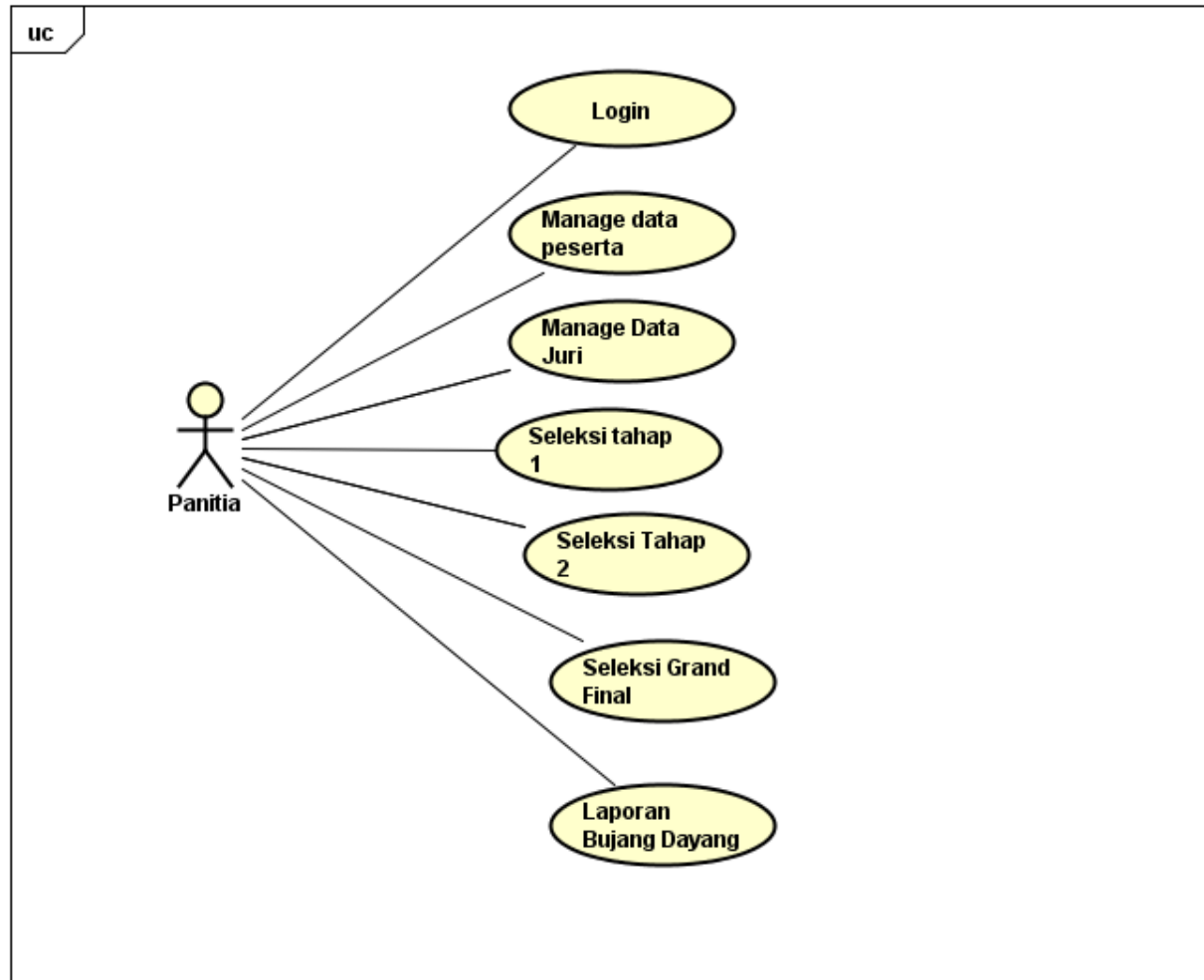

Gambar 2. Use case Diagram Pengguna Panitia

Dari gambar diatas dapat dijelaskan bahwa panita berperan dalam pengolahan data peserta, data juri, proses seleksi hingga laporan ujang dayang. Untuk user juri bisa melihat data peserta dan melakukan penilaian dari seleksi tahap 1, seleksi tahap 2 hingga seleksi randfinal dan dapat melihat hasil penilaian seperti gambar dibawah ini:

\section{Hasil Implementasi}

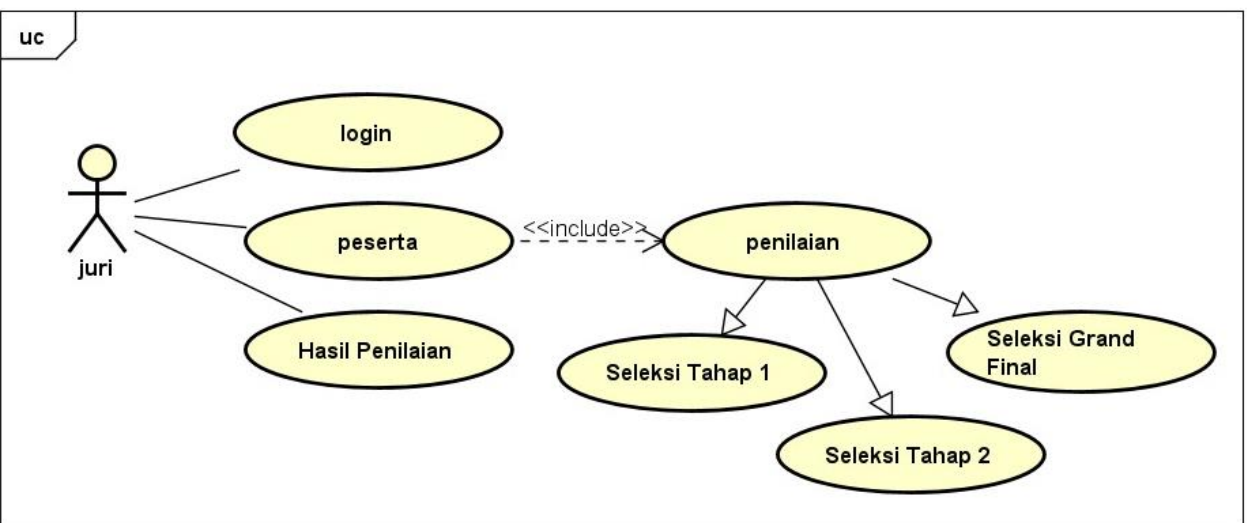

Gambar 3. Use Case Diagram Juri

Setelah dilakukan analisa bobot dan konversi nilai ke bilangan fuzzy, maka dilakukan perhitungan nilai sesuai rumus metode SAW ang dimasukkan kedalam codingan sistem dan didapatkan implementasi sistem sebagai berikut :

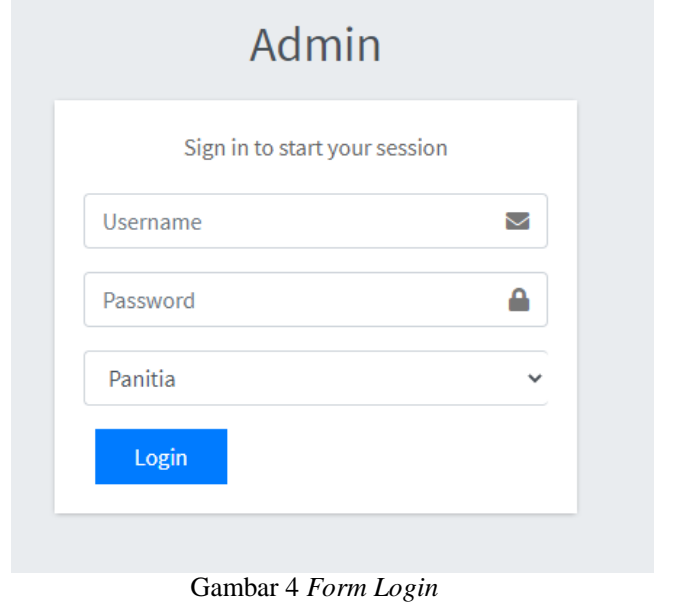


Setelah user berhasil login sebagai panitia, maka user bisa masuk ke dalam halaman menu utama seperti gambar dibawah ini :
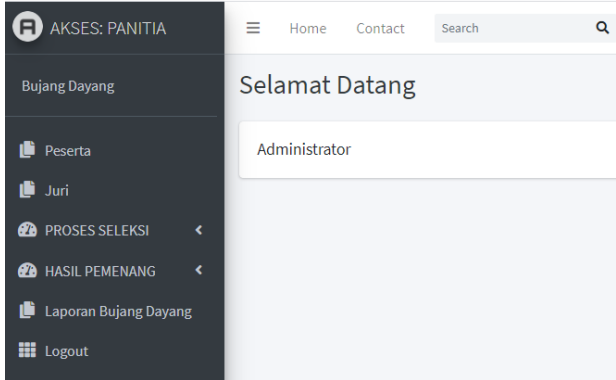

Panitia dapat melakukan klik menu sesuai dengan yang diinginkan seperti mengisi data pesera, data juri, melakukan proses seleksi, melihat hasil pemenang dan melihat laporan penilai bujang dayang. Setelah data pesertam data juri diinput kemudian dilkuakn proses seleksi tahap 1, tahap 2 dan grandfinal. Berikut ini merupakan halaman proses seleksi grand final

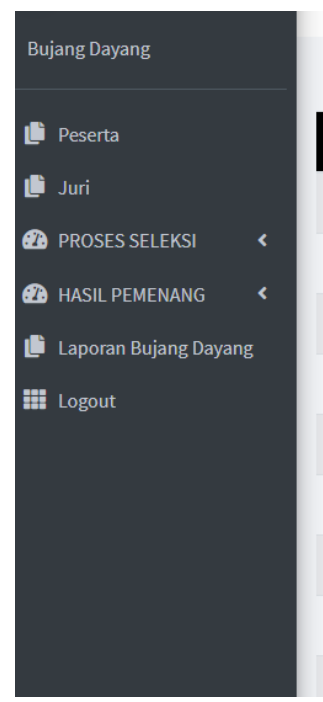

HASIL KEPUTUSAN SELEKSI GRAND FINAL BUJANG DAYANG KOTA PANGKALPINANG

\begin{tabular}{|ccccccc}
\hline No & ID Peserta & Nama Juri & Nama Peserta & Tanya Jawab & Penampilan & Gesture Tubuh \\
\hline 1 & 1 & Santi & akuuu & Sangat Menguasai & Sangat Baik & Sangat Baik \\
\hline 2 & 1 & Randi & akuuu & Sangat Menguasai & Baik & Baik \\
\hline 3 & 1 & Busri & akuuu & Sangat Menguasai & Sangat Baik & Sangat Baik \\
\hline 4 & 1 & Putri & akuuu & Sangat Menguasai & Baik & Baik \\
\hline 5 & 1 & Purnama Sari & akuuu & Sangat Menguasai & Sangat Baik & Baik \\
\hline 6 & 3 & Santi & Suai & Menguasai & Baik & Baik \\
\hline 7 & 3 & Randi & Suai & Menguasai & Baik & Baik \\
\hline 8 & 3 & Busri & Suai & Menguasai & Baik & Baik \\
\hline 9 & 3 & Putri & Suai & Menguasai & Baik & Baik
\end{tabular}

Dari hasil yang sudah diinput oleh para juri, maka didapatkan hasil dari seleksi tahap grandfinal yang akan dilakukan normalisasi kedalam bilangan fuzzy dari masing-masing kriteria tersebut seperti gambar dibawah ini :

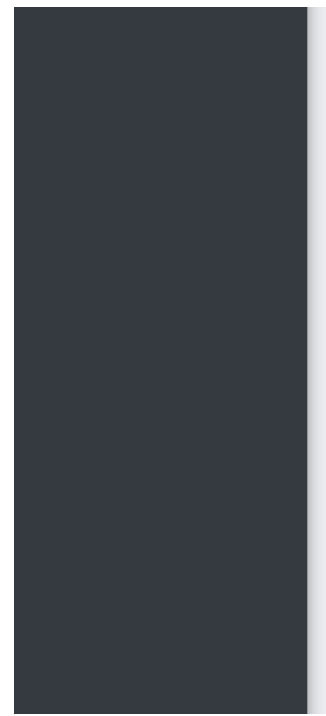

\begin{tabular}{|c|c|c|c|c|c|c|}
\hline \multicolumn{7}{|c|}{ MATRIK NORMALISASI } \\
\hline No & ID Peserta & Nama Juri & Nama Peserta & Tanya Jawab & Penampilan & Gesture Tubuh \\
\hline 1 & 1 & Santi & akuuu & 1 & 1 & 1 \\
\hline 2 & 1 & Randi & akuuu & 1 & 0.75 & 0.75 \\
\hline 3 & 1 & Busri & akuuu & 1 & 1 & 1 \\
\hline 4 & 1 & Putri & akuuu & 1 & 0.75 & 0.75 \\
\hline 5 & 1 & Purnama Sari & akuuu & 1 & 1 & 0.75 \\
\hline 6 & 3 & Santi & Suai & 0.75 & 0.75 & 0.75 \\
\hline 7 & 3 & Randi & Suai & 0.75 & 0.75 & 0.75 \\
\hline 8 & 3 & Busri & Suai & 0.75 & 0.75 & 0.75 \\
\hline 9 & 3 & Putri & Suai & 0.75 & 0.75 & 0.75 \\
\hline 10 & 3 & Purnama Sari & Suai & 0.75 & 0.75 & 1 \\
\hline
\end{tabular}

Gambar 6. Matrik Normalisasi proses tahap grandfinal

Setelah didapatkan hasil normalisasi dan konversi kedalam bilangan fuzzy, maka dilakukan perhitungan nilai dengan menggunakan metode SAW dan didapatkan hasil sebagai berikut : 


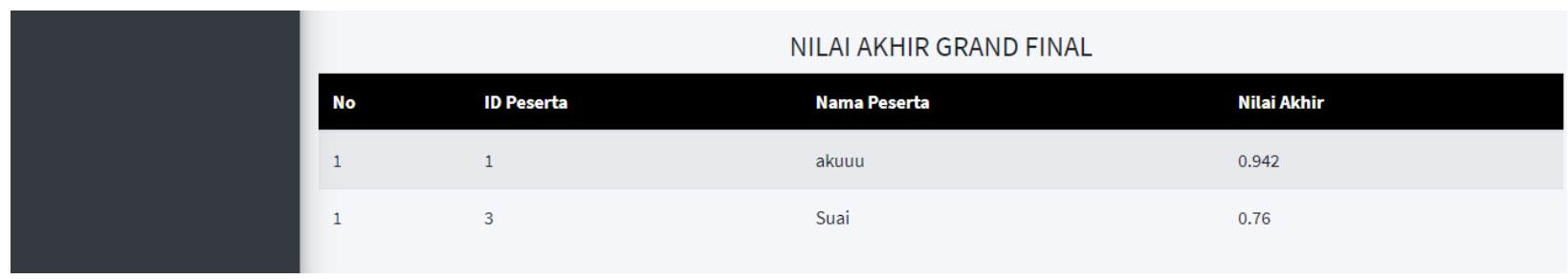

Gambar 7. Nilai Akhir grandfinal

Setelah didapatkan nilai akhir, maka selanjutnya akan didapatkan pemenang dari bujang dayang kota pangkalpinang yang bisa dilihat dalam sistem sebagai berikut :

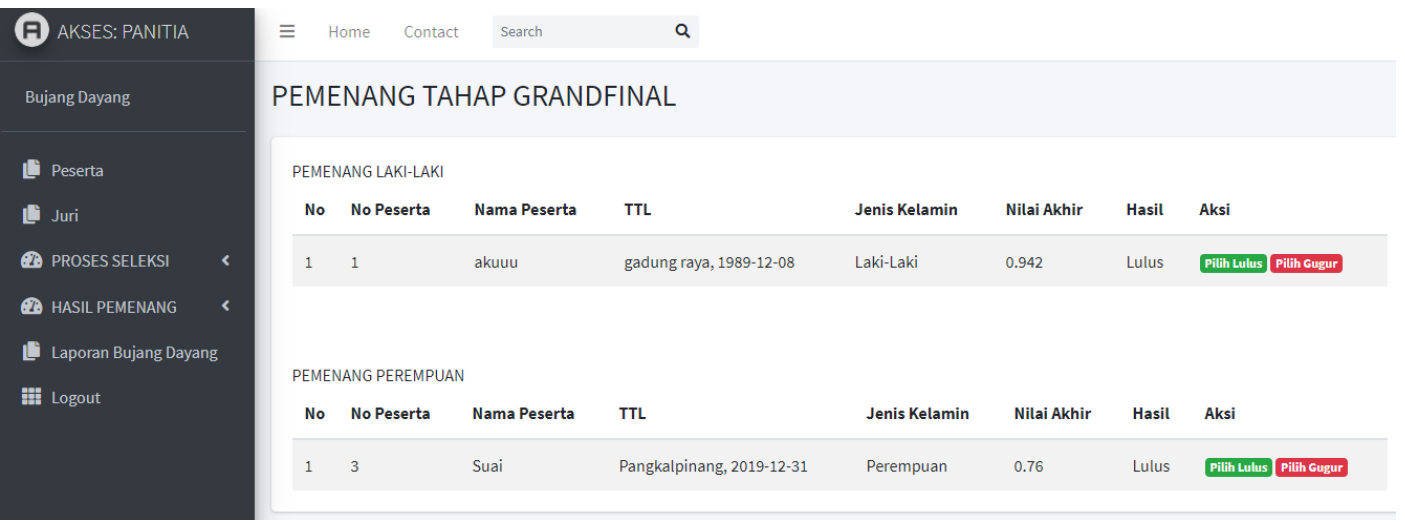

Gambar 8. Hasil Pemenang Bujang Dayang

\section{PENUTUP}

\section{A. Kesimpulan}

Dari hasil penelitian penerapan sistem pengambilan keputusan pemilihan bujang dayang kota Pangkalpinang, maka dapat diambil kesimpulan berikut.

1) Sistem Pengambilan keputusan pemilihan bujang dayang kota Pangkalpinang dengan metode FMADM dan SAW berhasil dirancang dan dibangun sehingga mampu mempermudah proses penilaian pemilihan bujang dayang kota Pangkalpinang.

2) Metode Simple Additive Wighting (SAW) berhasil menentukan pemenang bujang dayang kota Pangkalpinang berdasarkan nilai yang didapatkan masing-masing peserta

3) Sistem Pengambilan keputusan pemilihan bujang dayang kota Pangkalpinang dengan metode FMADM dan SAW berhasil menampilkan pemenang dengan perhitungan yang akurat.

B. Saran

Penelitian ini masih jauh dari sempurna. Oleh karena itu, penulis memberikan saran-saran berikut untuk penelitian selanjutnya.

1) Untuk penelitian selanjutnya bisa menerapkan aplikasi yang bisa diinstal di handphone sehingga lebih efisien dalam hal penggunaan sistem nya.

2) Aplikasi yang dikembangkan mampu diterapkan di android maupun IOS sehingga bisa digunakan oleh semua user yang terlibat.

\section{PENGAKUAN}

Makalah ini dibuat untuk memenuhi salah satu komponen dalam Tri Dharma Perguruan Tinggi dan disponsori oleh Lembaga Penelitian dan Pengabdian Masyarakat ISB Atma Luhur.

\section{DAFTAR PUSTAKA}

[1] Afshari , Alireza., Mojahed, Majid,. and Yusuff, Rosnah Mohd.(2010). "Simple Additive Weighting approach to Personnel Selection problem". International Journal of Innovation, Management and Technology, Vol. 1, No. 5

[2] Mukodimah, Siti., etc.(2018). "Fuzzy Simple Additive Weighting and its Application to Toddler Healthy Food". International Journal of Pure and Applied Mathematics, Volume 118 No. 7

[3] Muslihudin,Muhammad. (2018). "The Priority of Rural Road Development using Fuzzy Logic based Simple Additive Weighting”. International Journal of Pure and Applied Mathematics Volume 118 No. 8 
[4] Sahir,Syafrida Hafni., Rosmawati,R., Minan,Kresna. (2017). "Simple Additive Weighting Method to Determining Employee Salary Increase Rate”. IJSRST Vol. 3 No. 8

[5] Pratiwi,Dyah., Lestari,Juliana Putri., R,Dewi Agushinta. (2014). "Decision Support System to Majoring High School Student Using Simple Additive Weighting Method ". International Journal of Computer Trends and Technology (IJCTT) - volume 10 number

[6] Nurdiyanto,Heri., Meilia,Heryanita. (2016). "Sistem Pendukung Keputusan Penentuan Prioritas Pengembangan Industri Kecil Dan Menengah Di Lampung Tengah Menggunakan Analitical Hierarchy Process (Ahp)”. Seminar Nasional Teknologi Informasi dan Multimedia ISSN : 23023805 .

[7] Irawan, Yan., Wahyuningsih, Delpiah. (2018). "Pendaftaran Peserta Didik Baru Dengan Metode Simple Additive Weighting(SAW)". Jurnal Sistem Informasi Vol. 5 No. 1

[8] Pradana, Harrizki Arie, dkk. (2020). "Pengambilan Keputusan Pemilihan Sekolah Dasar Islam Menggunakan Metode SAW dan FMADM di Pangkalpinang”. Jurnal SISFOKOM (Sistem Informasi dan Komputer), Volume 09, Nomor 01, PP 132 - 137

[9] Yanuari, Elly, dkk. (2019). "Rekomendasi Kelayakan Peserta Rumah Sehat Baznas-Timah Pangkalpinang Dengan Metode SAW". Nusantara Journal Of Computers and Its Application. ISSN 2527-9815 Vol. 4 No. 2

[10] S. Suhada, T. Hidayatulloh, and S. Fatimah, "PENERAPAN FUZZY MADM MODEL WEIGHTED PRODUCT DALAM PENGAMBILAN KEPUTUSAN KELAYAKAN PENERIMAAN KREDIT DI BPR NUSAMBA SUKARAJA”, Jurnal JUITA, Vol. 6, No. 1, Mei 2018. 10.30595/juita.v6i1.2517.

[11] M. M. Yusro and R. Wardoyo, “APLIKASI METODE FUZZY MULTIATTRIBUTE DECISION MAKING BERBASIS WEB DALAM PEMILIHAN CALON KEPALA DAERAH DI INDONESIA”, Indonesian Journal of Computing and Cybernetics System, Vol.7, No. 1, Januari 2013. https://doi.org/10.22146/ijccs.3056.

[12] A. Nurzahputra, A. R. Pranata, and A. Puwinarko, "SISTEM PENDUKUNG KEPUTUSAN PEMILIHAN LINE-UP PEMAIN SEPAK BOLA MENGGUNAKAN METODE FUZZY MULTIPLE ATTRIBUTE DECISION MAKING DAN K-MEANS CLUSTERING", JURnal JTSISKOM, Vol. 5, No. 3, Juli 2017. https://doi.org/10.14710/jtsiskom.5.3.2017.106-109

[13] Pipyros,Kosmas., etc. (2016). "Cyber-Attacks Evaluation Using Simple Additive Weighting Method On The Basis Of Schmitt's Analysis". Tenth Mediterranean Conference on Information Systems (MCIS) 